Gautam D1

Paudel D1

Thapa $\mathbf{S}^{2}$

Sharma S K ${ }^{3}$

Department of Otorhinolaryngology and Head \& Neck Surgery

National Academy of Medical Sciences,

Bir Hospital Kathmandu, Nepal 1

Department of Otorhinolaryngology and Head \& Neck Surgery

B. P. Koirala Institute of Health

Sciences, Dharan, Nepal 2

Department of Internal Medicine

B. P. Koirala Institute of Health

Sciences, Dharan, Nepal 3

Correspondence:

Dr. Dipendra Gautam

Department of Otorhinolaryngology \&

Head and Neck Surgery

National Academy of Medical

Sciences,Bir Hospital Kathmandu,

Nepal

Email:drdipendragautam.DG@gmail.

com

\title{
CORELATION OF HEARING LOSS WITH VARIOUS BIOCHEMICAL AND DISEASE PARAMETERS IN PATIENTS WITH CHRONIC KIDNEY DISEASE
}

Objectives:

To correlate the hearing loss with duration of the disease, stage of the disease, ototoxic drugs use, co-morbidity and biochemical parameters in patients with chronic kidney disease (CKD).

Material and Methods:

This prospective study of 50 CKD patients was conducted in the department of ototolaryngology head and neck surgery and department of internal medicine, B. P. Koirala Institute of Health Sciences, Dharan, between December 2008 to November 2009. The blood investigation report of the patients were noted. Otological examination was carried out including tunning fork test and pure tone audiometry. Middle ear pathology and conductive hearing loss were excluded. Data was collected and analyzed.

Results:

Sensory neural hearing loss was higher in patients with; end stage renal disease (stage-5), co-morbidity, haemoglobin level less than 8.5, duration of CKD greater than 2 years, and ototoxic drug administration, but not statistically significant (P-value $>0.05$ ). Hearing loss in patients with CKD was not influenced by fasting blood sugar, serum urea, creatinine, sodium, potassium, calcium and serum phosphorus. (P-value $>0.05)$

\section{Conclusion:}

The hearing loss in patients with chronic kidney disease was not significantly related with stage of CKD, co-morbidity, ototoxic drug use, fasting blood sugar, serum urea, creatinine, sodium, potassium, calcium and serum phosphorus ( $P$-value $>0.05$ ). The sensory neural hearing loss in these patients may be due to the advanced age and possible accelerated presbyacusis by the disease.

Key w ord s: Chronic kidney disease, Pure tone audiometry, Sensory neural hearing loss, Ototoxicity
I NTRODUCTION

Disorders of metabolism including chronic kidney disease are reported to results in sensorineural hearing loss. In clinical practice, sensory neural hearing loss are commonly found in these patients but the etiology remains unclear. The present study was conducted to correlate hearing loss in patients with chronic kidney disease and biochemical parameters of the chronic kidney disease. The various parameters studied are: duration of the disease, stage of the disease, associated co-morbidity, use of ototoxic drugs, blood sugar level, urea, creatinine, haemoglobin, sodium, potassium, calcium, and phosphorous level. Many similarities exist between the nephron and the stria vascularies of the cochlea and hearing loss have been reported in patients with chronic kidney disease. It has been shown that there is an immunological connection between the kidney and inner ear in that antibodies raised against the nephron also deposit in the stria vascularis. 1 Although the gross anatomy of the kidney and cochlea differ greatly, there are many similarities at the ultra-structural level. Because of similar molecular structure, they can be damaged by the same drugs, such as overdose of diuretics. In the developing baby, both the ear and kidney develop around the 5th to 8th week of pregnancy. For some reason, both membranes tend to deteriorate over time, leading to progressively worse kidney problems and worsening hearing. Various pharmacological agents act both on the inner ear and kidney and these agents can be both nephrotoxic and ototoxic.2 Aminoglycoside antibiotics, alcohol, frusemide, vancomycin,atenolol etc are example of ototoxic drugs. Combination of these drugs eg.Frusemide when taken with alcohol, aminoglycosides further enhances the toxicity of these drugs.

In 2000, The National kidney foundation (NKF) kidney disease outcome quality initiative (K/DOQI) advisory board approved development of clinical practice guidelines to define "chronic kidney disease.1" Sensory neural hearing loss results from lesions of the cochlea especially the hair cells of organ of corti, eighth nerve or central auditory pathways. 4 Disorders of metabolism as well as endocrine disorders are reported to results in sensorineural hearing loss including the diabetes mellitus, hypothyroidism, hyperlipoproteinemia, renal failure, hyperuricemia, acromegaly, addison's diseases and pheochromocytoma.5

MATERIALS AND METHOD

This prospective study was conducted in the department of Ototolaryngology Head \& Neck Surgery and department of Internal
Medicine, B. P. Koirala Institute of Health Sciences, Dharan, between December 2008 to November 2009. Fifty consecutive CKD patients above five years of age without history of ear disease prior to CKD, without conductive hearing loss, without history of sensory neural hearing loss prior to development of CKD (due to other causes e.g. noise, infection) were included. Patients below five years were not included in this study because of their inabilities to interpret audiometry tones appropriately. Informed consent was taken from all patients. Ethical clearance was taken from the ethical committee of the institute. Chronic kidney disease (CKD) diagnosed according to NKF/DQLI criteria. Clinical history and physical examination was carried out in all the patients according to performa. Patient's occupational history was taken to exclude risk factors for hearing loss e.g. noise exposure. Birth and developmental history was taken to exclude congenital and other causes of acquired hearing loss before the development of CKD. Drug history was taken, especially the ototoxic drugs. Past history of ear trauma and head injury was taken to rule out the prior hearing loss. Otological examination was carried out to exclude middle ear pathology. All the subjects had normal ears at otoscopy. Tuning fork tests were carried out with $512 \mathrm{~Hz}$ tuning fork. Rinne's test was positive and Weber's test was centralized in all the patients. Pure tone audiometry was carried on each patient in a sound-proof room. Calibrated Italian diagnostic audiometer (Amploid460) was chosen for PTA test and was performed by a trained speech and hearing pathologist. Test was done by a single person to ensure test-retest reliability. No patients had air bone gap in the PTA. Threshold for hearing was determined separately for each ear.

The investigation report of various blood and biochemical parameters of the patients were noted at the time of examination including serum haemoglobin, fasting blood sugar, calcium, serum phosphorus, urea, creatinine, sodium and potassium. The collected data was entered into Microsoft Excel Spreadsheet and was analyzed using SPSS version 11.5. Sensory neural hearing loss was correlated with duration of the disease, stage of the disease, ototoxic drug use and biochemical parameters in patients with chronic kidney disease.

RESULTS:

Total of 50 patients were included in our study. (Table-1) Mean age of CKD patients was 41.36 years (Range $=17-73$ years). There were 24 $(57 \%)$ females and $26(43 \%)$ males. There were ten patients $(20 \%)$ in stage-2, seven (14\%) patients in stage-3, seven patients (14\%) in stage4 , and twenty-six patients (52\%) in stage-5 chronic kidney disease. The mean duration of chronic kidney diseases since detection was 
27.98 months. (SD=33.43) (Range=1-152 months). Out of 50 CKD patients; seven patients had diabetes mellitus; twelve had hypertension and fourteen had both diabetes mellitus and hypertension both as a co-morbid illness. Fifteen patients didn't have any known co-morbid illness. Out of 50 patients; twenty one patients had history of atenolol administration, ten patients had history of atenolol and frusemide administration, one patient had history of frusemide and amikacin administration and eighteen patients did not have any history of ototoxic drug administration. Two (4\%) patients had history of renal transplantation while 48(96\%) patients did not have any history of renal transplantation. Twenty seven $(54 \%)$ patients had history of dialysis and 23 (46\%) patients did not have any history of dialysis. Sensory neural hearing loss was present in $46 \%$ of CKD patients. High frequency hearing loss was the commonest abnormality found and was present in 31\% of CKD patients. Middle frequency sensory neural hearing loss was found in $8 \%$ and low frequency hearing loss was found in $7 \%$ of CKD patients. Mean hearing loss in, $250-500 \mathrm{~Hz}, 1,000$ $2,000 \mathrm{~Hz}$, and $4,000-8,000 \mathrm{~Hz}$ frequency range were $18.25 \pm 13.74 \mathrm{~dB}$, $18.75 \pm 14.11 \mathrm{~dB}$ and $39.66 \pm 28.96 \mathrm{~dB}$ respectively.

Correlation of hearing loss in with various parameter :

Hearing loss did not differ significantly ( $P$-value $>0.05)$ in patients having serum urea $\leq 40 \mathrm{mg} / \mathrm{dl}$ and serum urea $>40 \mathrm{mg} / \mathrm{dl}$, serum creatinine $\leq 1.2 \mathrm{mg} / \mathrm{dl}$ and serum creatinine $>1.2 \mathrm{mg} / \mathrm{dl}$, serum sodium $\leq 145 \mathrm{mmol} / \mathrm{L}$ and serum sodium $>145 \mathrm{mmol} / \mathrm{L}$, serum potassium $\leq$ $5.5 \mathrm{mmol} / \mathrm{L}$ and serum potassium $>5.5 \mathrm{mmol} / \mathrm{L}$, serum calcium $\leq 10$ $\mathrm{mg} / \mathrm{dl}$ and serum calcium $>10 \mathrm{mg} / \mathrm{dl}$, serum phosphorus $\leq 5 \mathrm{mg} / \mathrm{dl}$ and serum phosphorus $>5 \mathrm{mg} / \mathrm{dl}$. Hearing loss was not affected significantly with fasting plasma sugar level (P-value $>0.05)$ in patients with fasting plasma glucose $<126 \mathrm{mg} / \mathrm{dL}$ (euglycemic) and with fasting plasma glucose $\geq 126 \mathrm{mg} / \mathrm{dL}$ (hyperglycemic). Mean hearing loss in $\leq$ $2,000,250-500,1,000-2,000$ and $4000-8000 \mathrm{~Hz}$ were higher in CKD patients with $\mathrm{Hb}$ level less than $8.5 \mathrm{gm} / \mathrm{dl}$ than in patients with $\mathrm{Hb} \geq$ $8.5 \mathrm{gm} / \mathrm{dl}$, but not statistically significant. Mean hearing loss was higher in patients with stage-5 (ESRD) as compared to Stage-2, Stage3 and Stage-4 patients but was not statistically significant (P-value $>0.05$ ). Hearing loss in different frequency level was higher in patients having CKD for more than 2 years. However hearing loss did not differ significantly with duration of CKD since its detection. (P-value was $>0.05$ ). Mean hearing loss was higher in patients with CKD and Comorbid condition than in patients with CKD and no co-morbid condition and was statistically significant in all frequencies (P-value $>0.05$ ) (Table-2). Mean hearing loss was higher in CKD patients taking known ototoxic drug for more than one month than CKD patients without any known ototoxic drug use. However hearing loss did not differ significantly in two groups. (P-value $>0.05)($ Table- 3 )

[Fig. 1: Distribution of patients according to stage of disease

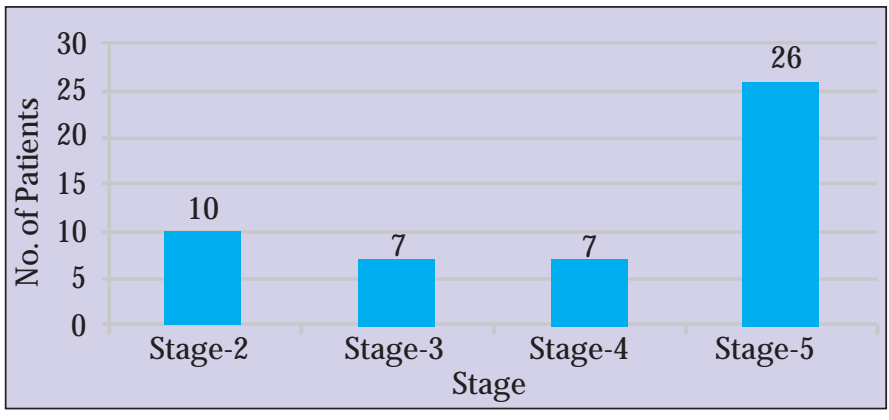

Fig. 2: Distribution of patients according duration of CKD

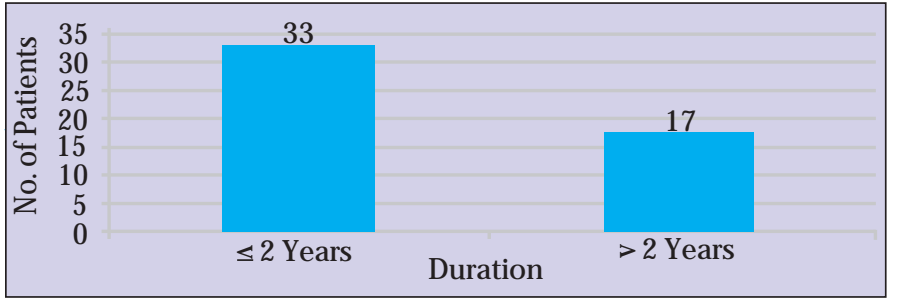

Fig. 3: Patients using ototoxic drugs

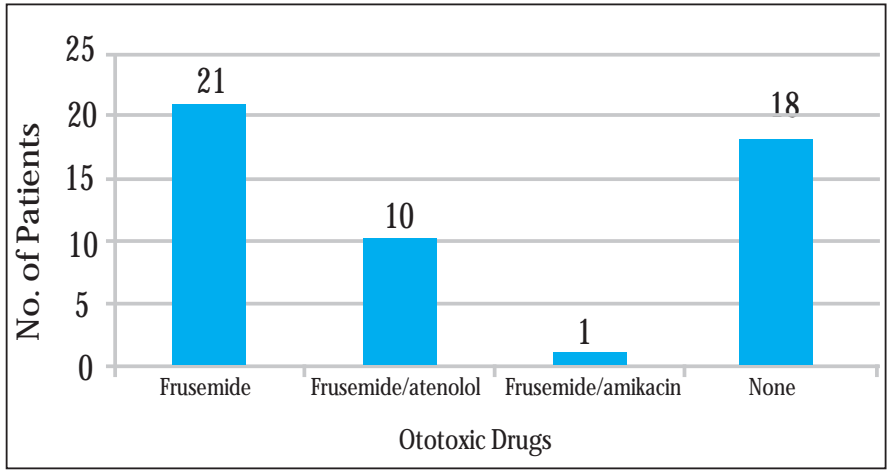

Table. 1: Age distribution

\begin{tabular}{|l|l|l|}
\hline Variable & Category & Total \\
\hline Age (in years) & $15-30$ & 19 \\
\hline \multirow{3}{*}{ Total } & $31-45$ & 8 \\
\cline { 2 - 3 } & $46-60$ & 17 \\
\cline { 2 - 3 } & $61-80$ & 6 \\
\hline & & 50 \\
\hline
\end{tabular}

Table. 2: Correlation of hearing loss with mean Serum urea

\begin{tabular}{|c|c|c|c|c|}
\hline \multirow{2}{*}{$\begin{array}{l}\text { Serum } \\
\text { urea(mg/dl) }\end{array}$} & \multicolumn{4}{|c|}{ Frequency } \\
\hline & $\leq 2,000 \mathrm{hz}$ & $250-500 \mathrm{hz}$ & $1,000-2,000 \mathrm{hz}$ & $\begin{array}{l}4,000- \\
8,000 \mathrm{hz}\end{array}$ \\
\hline $\begin{array}{ll}\leq 40 & \text { Mean } \\
(\mathrm{N}=5) & \mathrm{SD}\end{array}$ & $\begin{array}{l}9.60 \\
6.18\end{array}$ & $\begin{array}{l}14.00 \\
8.21\end{array}$ & $\begin{array}{l}11.50 \\
6.98 \\
\end{array}$ & $\begin{array}{l}32.20 \\
17.62 \\
\end{array}$ \\
\hline $\begin{array}{ll}>40 & \text { Mean } \\
(\mathrm{N}=45) & \mathrm{SD}\end{array}$ & $\begin{array}{l}19.96 \\
14.18\end{array}$ & $\begin{array}{l}18.72 \\
14.20\end{array}$ & $\begin{array}{l}19.55 \\
14.51\end{array}$ & $\begin{array}{l}40.48 \\
29.98\end{array}$ \\
\hline p-value & 0.115 & 0.472 & 0.229 & 0.549 \\
\hline
\end{tabular}

Table. 3: Correlation of hearing loss with mean Serum creatinine

\begin{tabular}{|l|c|c|c|c|}
\hline \multirow{2}{*}{$\begin{array}{c}\text { Serum } \\
\text { creatinine } \\
(\mathrm{mg} / \mathrm{dl})\end{array}$} & \multicolumn{4}{|c|}{ Frequency } \\
\cline { 2 - 5 } & $\mathbf{5 2 , 0 0 0 \mathrm { hz }}$ & $\mathbf{2 5 0 - 5 0 0 \mathrm { hz }}$ & $\mathbf{1 , 0 0 0 - 2 , 0 0 0 \mathrm { hz }}$ & $\begin{array}{c}\mathbf{4 , 0 0 0 -} \\
\mathbf{8 , 0 0 0 h z}\end{array}$ \\
\hline$\leq 1.2$ Mean & 12.66 & 9.16 & 18.33 & 57.33 \\
$(\mathrm{~N}=3)$ SD & 4.75 & 3.81 & 6.29 & 24.82 \\
\hline$>1.2$ Mean & 19.32 & 18.82 & 18.77 & 38.53 \\
$(\mathrm{~N}=47) S D$ & 14.23 & 13.95 & 14.50 & 29.07 \\
\hline p-value & 0.427 & 0.242 & 0.959 & 0.280 \\
\hline
\end{tabular}

Table. 4: Correlation of hearing loss with Serum sodium

\begin{tabular}{|c|c|c|c|c|}
\hline \multirow{2}{*}{$\begin{array}{c}\text { Serum } \\
\text { sodium } \\
\text { (mmol/L) }\end{array}$} & \multicolumn{4}{|c|}{ Frequency } \\
\cline { 2 - 5 } & $\mathbf{\mathbf { m } , 0 0 0 \mathrm { hz }}$ & $\mathbf{2 5 0 - 5 0 0 \mathrm { hz }}$ & $\mathbf{1 , 0 0 0 - 2 , 0 0 0 \mathrm { hz }}$ & $\begin{array}{c}\mathbf{4 , 0 0 0 -} \\
\mathbf{8 , 0 0 0 h z}\end{array}$ \\
\hline $\mathbf{S 1 4 5}$ Mean & 18.36 & 17.56 & 18.23 & 37.52 \\
$(\mathrm{~N}=\mathbf{4 1})$ SD & 14.86 & 14.81 & 15.20 & 30.14 \\
\hline$>145$ Mean & 21.50 & 21.39 & 21.11 & 49.39 \\
$(\mathrm{~N}=9)$ SD & 8.47 & 6.74 & 7.40 & 21.54 \\
\hline p-value & 0.546 & 0.455 & 0.585 & 0.270 \\
\hline
\end{tabular}

Table. 5: Correlation of hearing loss with mean Serum potassium

\begin{tabular}{|l|c|c|c|c|}
\hline \multirow{2}{*}{$\begin{array}{c}\text { Serum } \\
\text { potassium } \\
(\text { mmol/L) }\end{array}$} & \multicolumn{4}{|c|}{ Frequency } \\
\cline { 2 - 5 } & $\mathbf{5 2 , 0 0 0 \mathrm { hz }}$ & $\mathbf{2 5 0 - 5 0 0 \mathrm { hz }}$ & $\mathbf{1 , 0 0 0 - 2 , 0 0 0 \mathrm { hz }}$ & $\mathbf{4 , 0 0 0 - 8 , 0 0 0 \mathrm { hz }}$ \\
\hline$\leq 5.5$ Mean & 18.61 & 17.71 & 18.19 & 36.90 \\
$(\mathrm{~N}=36)$ SD & 9.12 & 8.28 & 9.13 & 21.47 \\
\hline$>5.5$ Mean & 19.75 & 19.64 & 20.18 & 46.75 \\
(N=14) SD & 22.46 & 22.88 & 22.86 & 42.95 \\
\hline p-value & 0.798 & 0.660 & 0.660 & 0.285 \\
\hline
\end{tabular}


Gautam et al: Corelation of Hearing Loss with

ChronicKidney Disease

Table.6: Correlation of hearing loss with mean Serum calcium

\begin{tabular}{|l|c|c|c|c|}
\hline \multirow{2}{*}{$\begin{array}{c}\text { Serum } \\
\text { calcium } \\
\text { (mg/dl) }\end{array}$} & \multicolumn{4}{|c|}{ Frequency } \\
\cline { 2 - 5 } & $\mathbf{2 2 , 0 0 0 \mathrm { hz }}$ & $\mathbf{2 5 0 - 5 0 0 h z}$ & $\mathbf{1 , 0 0 0 - 2 , 0 0 0 h z}$ & $\begin{array}{c}\mathbf{4 , 0 0 0 -} \\
\mathbf{8 , 0 0 0 h z}\end{array}$ \\
\hline $\mathbf{S 1 0 \text { Mean }}$ & 16.80 & 16.09 & 16.64 & 35.86 \\
$(\mathrm{~N}=\mathbf{4 1 )}$ SD & 8.11 & 7.68 & 8.68 & 28.74 \\
\hline$>10$ Mean & 28.61 & 28.05 & 28.33 & 56.94 \\
$(\mathrm{~N}=9)$ SD & 26.98 & 27.00 & 26.75 & 24.42 \\
\hline p-value & 0.020 & 0.016 & 0.023 & 0.047 \\
\hline
\end{tabular}

Table.7:Correlation of hearing loss with mean serum phosphorus.

\begin{tabular}{|l|c|c|c|c|}
\hline \multirow{2}{*}{$\begin{array}{c}\text { Serum } \\
\text { phosphorus } \\
\text { (mg/dl) }\end{array}$} & \multicolumn{4}{|c|}{ Frequency } \\
\cline { 2 - 5 } & $\mathbf{\leq 2 , 0 0 0 \mathrm { hz }}$ & $\mathbf{2 5 0 - 5 0 0 h z}$ & $\mathbf{1 , 0 0 0 - 2 , 0 0 0 h z}$ & $\begin{array}{c}\mathbf{4 , 0 0 0 -} \\
\mathbf{8 , 0 0 0 h z}\end{array}$ \\
\hline$\leq 5$ Mean & 17.80 & 17.91 & 17.22 & 38.52 \\
(N=18) SD & 10.41 & 9.40 & 9.50 & 21.18 \\
\hline$>\mathbf{5}$ Mean & 19.58 & 18.43 & 19.60 & 40.29 \\
(N=32) SD & 15.66 & 15.80 & 16.21 & 32.84 \\
\hline p-value & 0.673 & 0.899 & 0.571 & 0.838 \\
\hline
\end{tabular}

Table.8: Correlation of mean hearing loss with blood sugar.

\begin{tabular}{|c|c|c|c|c|}
\hline \multirow{2}{*}{$\begin{array}{c}\text { Fasting plasma } \\
\text { sugar (mg/dL) }\end{array}$} & \multicolumn{4}{|c|}{ Frequency } \\
\cline { 2 - 5 } & $\leq 2,000 \mathrm{hz}$ & $\mathbf{2 5 0 - 5 0 0 h z}$ & $\mathbf{1 , 0 0 0 - 2 , 0 0 0 \mathrm { hz }}$ & $\begin{array}{c}\mathbf{4 , 0 0 0 -} \\
\mathbf{8 , 0 0 0 h z}\end{array}$ \\
\hline$<126$ Mean & 20.21 & 18.58 & 20.08 & 45.15 \\
$(\mathrm{~N}=\mathbf{3 0})$ SD & 16.90 & 16.39 & 16.92 & 33.23 \\
\hline $\mathbf{2 1 2 6 \text { Mean }}$ & 17.86 & 17.00 & 17.75 & 16.75 \\
$(\mathrm{~N}=\mathbf{2 0})$ SD & 16.23 & 16.61 & 16.66 & 32.51 \\
\hline p-value & 0.529 & 0.692 & 0.745 & 0.920 \\
\hline
\end{tabular}

Table.9: Correlation of mean hearing loss with Hemoglobin level.

\begin{tabular}{|c|c|c|c|c|}
\hline \multirow{2}{*}{$\mathrm{Hb}(\mathrm{gm} / \mathrm{dl})$} & \multicolumn{4}{|c|}{ Frequency } \\
\cline { 2 - 5 } & $\leq 2,000 \mathrm{hz}$ & $\mathbf{2 5 0 - 5 0 0 \mathrm { hz }}$ & $\mathbf{1 , 0 0 0 - 2 , 0 0 0 \mathrm { hz }}$ & $\begin{array}{c}\mathbf{4 , 0 0 0 -} \\
\mathbf{8 , 0 0 0 h z}\end{array}$ \\
\hline$<8.5$ Mean & 20.40 & 19.16 & 19.52 & 39.16 \\
$(\mathrm{~N}=\mathbf{2 1}) \mathrm{SD}$ & 10.07 & 8.63 & 9.89 & 23.98 \\
\hline$\geq 8.5$ Mean & 17.86 & 17.58 & 18.18 & 40.01 \\
$(\mathrm{~N}=\mathbf{2 9}) \mathrm{SD}$ & 16.23 & 16.61 & 16.66 & 32.51 \\
\hline p-value & 0.529 & 0.692 & 0.745 & 0.920 \\
\hline
\end{tabular}

Table.10: Correlation of mean hearing loss with Stage of CKD.

\begin{tabular}{|c|c|c|c|c|}
\hline \multirow{2}{*}{ Stage of CKD } & \multicolumn{4}{|c|}{ Frequency } \\
\hline & $\leq 2,000 \mathrm{hz}$ & $250-500 \mathrm{hz}$ & $1,000-2,000 \mathrm{hz}$ & $4,000-8,000 \mathrm{hz}$ \\
\hline $\begin{array}{l}\text { Group-1(Stage-2,3,4) Mean } \\
(\mathrm{N}=24) \quad \text { SD }\end{array}$ & $\begin{array}{l}18.25 \\
17.69 \\
\end{array}$ & $\begin{array}{l}17.19 \\
17.91 \\
\end{array}$ & $\begin{array}{l}18.12 \\
18.02 \\
\end{array}$ & \begin{tabular}{|l|}
44.64 \\
33.76 \\
\end{tabular} \\
\hline $\begin{array}{ll}\text { Group-2(Stage-5) } & \text { Mean } \\
(\mathrm{N}=26) & \mathrm{SD} \\
\end{array}$ & $\begin{array}{l}19.55 \\
9.53 \\
\end{array}$ & $\begin{array}{l}19.23 \\
8.54 \\
\end{array}$ & $\begin{array}{c}19.33 \\
9.53 \\
\end{array}$ & $\begin{array}{l}35.06 \\
23.43 \\
\end{array}$ \\
\hline p-value & 0.744 & 0.605 & 0.767 & 0.246 \\
\hline
\end{tabular}

Table.11: Correlation of hearing loss with duration of CKD.

\begin{tabular}{|c|c|c|c|c|}
\hline \multirow{2}{*}{$\begin{array}{l}\text { Duration of } \\
\text { CKD(year) }\end{array}$} & \multicolumn{4}{|c|}{ Frequency } \\
\hline & $\leq 2,000 \mathrm{hz}$ & $250-500 \mathrm{hz}$ & $\begin{array}{l}1,000- \\
2,000 \mathrm{hz}\end{array}$ & $\begin{array}{c}4,000- \\
8,000 \mathrm{hz}\end{array}$ \\
\hline $\begin{array}{ll}\leq 2 \mathrm{yrs} & \text { Mean } \\
(\mathrm{N}=33) & \mathrm{SD}\end{array}$ & $\begin{array}{l}17.95 \\
8.42\end{array}$ & $\begin{array}{l}17.50 \\
8.26\end{array}$ & $\begin{array}{l}17.65 \\
8.47\end{array}$ & $\begin{array}{l}38.24 \\
21.55\end{array}$ \\
\hline $\begin{array}{ll}>2 y r s & \text { Mean } \\
(\mathrm{N}=17) & S D\end{array}$ & $\begin{array}{l}20.82 \\
21.10\end{array}$ & $\begin{array}{l}19.71 \\
20.93\end{array}$ & $\begin{array}{l}20.88 \\
21.41\end{array}$ & $\begin{array}{l}42.41 \\
40.34\end{array}$ \\
\hline $\mathrm{P}$-value & 00.495 & 0.596 & 0.449 & 0.635 \\
\hline
\end{tabular}

Table.12: Correlation of mean hearing loss with comorbidity

\begin{tabular}{|c|c|c|c|c|c|}
\hline \multirow{2}{*}{\multicolumn{2}{|c|}{ Ototoxic drugs }} & \multicolumn{4}{|c|}{ Frequency } \\
\hline & & $\leq 2,000 \mathrm{hz}$ & $250-500 \mathrm{hz}$ & $\begin{array}{c}1,000- \\
2,000 \mathrm{hz}\end{array}$ & $\begin{array}{l}4,000- \\
8,000 \mathrm{hz}\end{array}$ \\
\hline $\begin{array}{l}\text { With Ototoxic drugs } \\
(\mathrm{N}=32)\end{array}$ & $\begin{array}{l}\text { Mean } \\
\text { SD }\end{array}$ & $\begin{array}{l}20.89 \\
16.46\end{array}$ & $\begin{array}{l}20.23 \\
15.82\end{array}$ & $\begin{array}{l}20.62 \\
16.49 \\
\end{array}$ & $\begin{array}{l}34.67 \\
24.84\end{array}$ \\
\hline $\begin{array}{l}\text { Without Ototoxic drugs } \\
(\mathrm{N}=18)\end{array}$ & $\begin{array}{l}\text { Mean } \\
\text { SD }\end{array}$ & $\begin{array}{l}15.44 \\
6.62 \\
\end{array}$ & $\begin{array}{l}14.72 \\
8.22 \\
\end{array}$ & $\begin{array}{l}15.42 \\
7.73\end{array}$ & $\begin{array}{l}48.52 \\
34.09 \\
\end{array}$ \\
\hline p-value & & 0.187 & 0.176 & 0.214 & 0.105 \\
\hline
\end{tabular}

Table.13 : Correlation of mean hearing loss with ototoxic drugs

\begin{tabular}{|c|c|c|c|c|c|}
\hline \multirow{2}{*}{\multicolumn{2}{|c|}{ Ototoxic drugs }} & \multicolumn{4}{|c|}{ Frequency } \\
\hline & & $\leq 2,000 \mathrm{hz}$ & $250-500 \mathrm{hz}$ & $\begin{array}{c}1,000- \\
2,000 \mathrm{hz}\end{array}$ & $\begin{array}{l}4,000- \\
8,000 \mathrm{hz}\end{array}$ \\
\hline $\begin{array}{l}\text { With Ototoxic drugs } \\
(\mathrm{N}=32)\end{array}$ & $\begin{array}{l}\text { Mean } \\
\text { SD }\end{array}$ & $\begin{array}{l}20.89 \\
16.46\end{array}$ & $\begin{array}{l}20.23 \\
15.82\end{array}$ & \begin{tabular}{|l|}
20.62 \\
16.49 \\
\end{tabular} & $\begin{array}{l}34.67 \\
24.84\end{array}$ \\
\hline $\begin{array}{l}\text { Without Ototoxic drugs } \\
(\mathrm{N}=18)\end{array}$ & $\begin{array}{l}\text { Mean } \\
\text { SD }\end{array}$ & $\begin{array}{l}15.44 \\
6.62\end{array}$ & $\begin{array}{c}14.72 \\
8.22 \\
\end{array}$ & $\begin{array}{l}15.42 \\
7.73\end{array}$ & $\begin{array}{l}48.52 \\
34.09 \\
\end{array}$ \\
\hline p-value & & 0.187 & 0.176 & 0.214 & 0.105 \\
\hline
\end{tabular}

\section{DISCUSSION}

Sensory neural hearing loss of unknown etiology commonly found in patients with chronic kidney disease. With this background, we conducted the present study to correlate the hearing loss with duration of the disease, stage of the disease, ototoxic drug use, co-morbidity and biochemical parameters in patients with chronic kidney disease. There were fifty patients of CKD in our study. The patients were between 17 to 73 years of age. Mean age of patients was 41.36 years (SD \pm 16.37 years; Range 17-73 years). There were 24 (48\%) females and $26(52 \%)$ males. Our study was similar to the study done by Morton 6 et al and Gatland 7 et al. We had taken all the CKD patients irrespective of the hemodialysis and renal transplantation. We did not take gender as a study parameter. Study done by Bains et al. showed no correlation of hearing loss with gender. 8 We found hearing loss in $46 \%$ of CKD patients. High frequency hearing loss was the commonest abnormality and was found in 31\% of CKD patients. Middle and low frequency hearing loss was found in $8 \%$ and $7 \%$ of CKD patients respectively. Sensory neural hearing loss was higher in patients with end stage renal disease (stage-5), co-morbidity, haemoglobin level less than 8.5, duration of CKD greater than 2 years, and ototoxic drug administration, but was not statistically significant (P-value $>0.05$ ). Hearing loss in patients with CKD was not influenced by fasting blood sugar, serum urea, creatinine, sodium, potassium, calcium and phosphorus level ( $P$-value $>0.05$ ). Nikolopaulous et al studied hearing acuity in 46 child ren and adolescents suffering from renal insufficiency. Sensory neural hearing loss of unknown cause was found in 14 patients (30.4\%). Hearing loss was not influenced by the various hematological, clinical parameters. They concluded that the relationship between renal insufficiency and hearing loss was mainly due to the advanced age and the possible accelerated presbyacusis of the patients that had been studied in the survey. 9 Study done by Bains. et al, showed no correlation of hearing loss with gender, degree of renal failure, and serum sodium. Hearing loss was seen in $70 \%$ of stage- 3 and 4 chronic kidney disease and $60 \%$ in stage- 5 . The intensity of hearing loss was variable.8 Morton et al, studies showed a high incidence of sensorineural hearing loss in chronic renal failure. The cause of the hearing loss was not established. It was unrelated neither to the number of treatments nor to the length of renal failure, or urea and creatinine levels. They showed no relationship between hearing loss and potentially ototoxic drugs in CKD patients. 10 Study of kingerman $A B$, showed a high incidence of high-frequency impairment which could not be attributed to age, noise exposure, ototoxicity, or hereditary. 12 Mancini et al found significant correlation of hearing loss with the administration of ototoxic drugs (aminoglycosides and furosemide). 11 In our study higher degree of hearing loss was found in patients with history of ototoxic drugs administration but no statistically significant correlation was found between hearing loss and ototoxic drugs.

\section{CONCLUSION}

SNHL of unknown etiology is common in patients with CKD and is not significantly influenced by stage of CKD, co-morbidity, ototoxic drug administration, fasting blood sugar, serum urea, creatinine, sodium, potassium, calcium and phosphorus. (P-value $>0.05$ ) The hearing loss in these patients may be due to advanced age and the possible accelerated presbyacusis by the disease.

\section{REFERENCES:}

1. Quick CA, Fish A, Brown C The relationship between cochlea and kidney. Laryngoscope 1973; 83, 1469-82

2. Bergstrom $L$, Jenkins $P$, Sando I, English GM. Hearing loss in renal diseases- clinical and pathological studies Ann Ottol 1973; 82; 55576 
3. Levey AS, Coresh J, Balk E. Practice guidelines for chronic kidney disease: evaluation, classification, and stratification National Kidney Foundation; Ann. Intern. ed. 2003; July15; 139(2): 137-47

4. A.Fitzgerald OC. Examination of the ear; Scott-Brown's Otolaryngology, volume-3, 6th Edition, Butterworth Heinemann, oxford, 1997; 15-16.

5. Lam Hoe Yeoh; Causes of hearing disorders. Scott-Brown's Otolaryngology, volume-2, 6th Edition, Butterworth Heinemann, Oxford, 1997; 15-16.

6. L.P. Morton, L. Reynolds, R. Zent, B.L. Rayne Hearing Thresholds in CAPD Patient. Clinical Otolaryngology and Allied Sciences 2001 Jun; 26(3):235-42

7. D. Gatland, B. Tucker, S. Chalstrey, M. Kenne, L Baker. Hearing loss in chronic renal failure- hearing threshold changes following haemodialysis. Journal of Royal Society Medicine, 1984; 587-589.
8. Bains H, Chopra J, Sandhu B. Cochlear Function in Chronic Kidney Disease and Renal Transplantation. Transplantation Proceedings; Volume 39, Issue 5, Pages 1465 - 1468

9. John B. Booth; sudden and fluctuant sensorineural hearing loss, Scott-Brown's Otolaryngology, vol 3.6th Ed Butterworth Heinemann, oxford, 1997, 31-32.

10. L.P. Morton, L. Reynolds, R. Zent, B.L. Rayner. Hearing Thresholds in CAPD Patient. Clinical Otolaryngology and Allied Sciences. 2001 un;26(3):235-42

11. M. L. Mancini, L. Dello Strologo, P. M. Bianchi, L. Tieri and G. Rizzoni Sensorineural hearing loss in patients reaching chronic renal failure inchildhood. Pediatric Nephrology. 1996 Feb;10(1):38-40

12. Kingerman AB, Solangi KB, Ventry IM, Goodman AI,Hearing impairment associated with chronic renal failure. Laryngoscope; $1981 ; 91 ; 583-92$ 